\title{
保障措置のための使用済燃料中の核物質量評価 燃焼計算コード検証委員会の活動
}

\author{
電力中央研究所 名内 泰志，笹原 昭博
}

\begin{abstract}
原子力発電所から日本原燃侏六ヶ所再処理工場 (RRP)へ使用済燃料集合体を搬出する際, 核 物質であるウラン，プルトニウム同位体の重量の燃焼計算コードによる計算值が報告される。 一方, 再処理の過程では, これらの核物質量が物理的に計量される。計算值と計量值の差を受 け払い間差異 (Shipper and Receiver Difference：SRD) という。電力中央研究所は, 産官学の 専門家を集めて委員会を設け, SRD 発生の要因を検討した。燃焼計算コードは新設計の燃料 集合体の導入等に応じて更新され，核物質量は燃料の使用時期毎の燃焼計算コードで評価され ている。更新でより詳細な燃焼計算手法の導入が進み, 将来 SRD が減少する傾向にあること を確認した。
\end{abstract}

\section{I 、はじめに}

日本は核兵器不拡散条約 (NPT) に加盟しており，国内 の電力会社や原子燃料メーカー等の原子力事業者は, ウ ラン $(\mathrm{U})$ やプルトニウム $(\mathrm{Pu})$ 等の核物質を適切に管理す る義務を負っている。一方, 国及び国際原子力機関 (IAEA) は，核物質が平和目的にのみ使用され，軍事目的 に転用されていないこと，未申告の核物質がないことを， 核物質の入った容器の封じ込め監視や, 物理的な計量 (重 量測定等)により，検認(これを保障措置と呼ぶ)する。

原子力事業所間で核物質である核燃料を移動する際 は，その払い出した核物質の量と受け取った核物質の量 が妥当な範囲で合致する必要がある。この核物質の払い 出し量と受け取り量との間の差異を SRD という。

国内の原子力発電所から日本原燃株六ヶ所再処理工場 (RRP) に核然料が輸送，処理される場合は，RRPでは 再処理工程で, 重量測定, 元素分析等により複数の燃料 集合体の核物質量をまとめて計量し，それを受け取り量 とする。

一方, 各発電所では, 計量管理単位である燃料集合体 毎に核物質量を計算する。RRPで計量にかかった燃料 集合体の核物質量計算值を合算し，これを払い出し量と する。この両者の差をもって SRD としている(第 1 図)。

核物質量の計算值にも, 計量值にも誤差はあるため, 通常は SRD が生じる。RRPでは平成 $18 \sim 19$ 年度に実 際の使用済燃料を処理する最終試験 (アクティブ試験) が 実施され，この試験に使用された燃料の SRD が評価さ れた。この值は IAEA に報告され，適切な範囲にある

Estimation of Amount of Nuclear Material in Spent Fuel for SRD ; Activity of the Committee on Burn-up Calculation Code Verification : Yasushi NAUCHI, Akihiro SASAHARA.

(2014 年 6 月 11 日 受理)

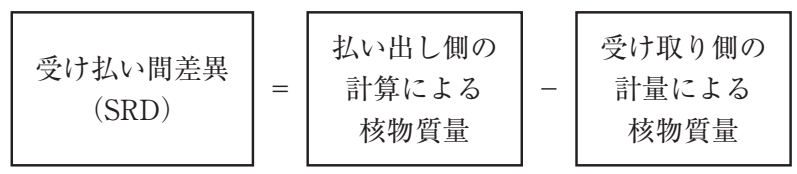

第 1 図 RRP での再処理での受け払い間差異 $(\mathrm{SRD})$ 評価

と了承されたが, 使用済燃料再処理の本格化を前に, 事 業者は SRD 低減に向けた継続的な努力を IAEA から求 められた。このため, 払い出し側の核物質量の誤差要因 である燃焼計算 (原子炉内の燃料の核変換をシミュレー ションする計算コードを用いた計算) に関する調査が必 要となった。

電力中央研究所は，「燃焼計算コード検証委員会」を平 成 21 年 4 月〜平成 24 年 3 月の期間設置し, RRP で再 処理された燃料の燃焼計算の問題点と, 今後の改善方法 等を議論した。委員会は, 大学, 研究機関等の燃焼計算 と保障措置の専門家および, 電気事業, 原子燃料メー カー等の産官学からのオブザーバで構成された。以下で は Puの SRD に関する評価方法と本委員会で検討した 内容について概要を紹介する。

\section{SRD の評価手法}

\section{1. 発電所での燃焼計算}

PWR においては，運転期間中，原子炉の出力や炉内 温度, 中性子束分布を測定する。この測定から各燃料集 合体の出力分布と燃焼度分布が得られる。一方, 燃料集 合体のタイプ毎に設計データ(形状と組成)を用いて水平 方向 2 次元の燃焼計算 (集合体燃焼計算)を実施し, いろ いろな燃焼度に対する $\mathrm{U}$ と $\mathrm{Pu}$ の同位体組成の計算值を まとめたデータベース (同位体テーブル)を用意する。測 定で得られた燃料集合体の高さ方向 (軸方向)位置の燃焼 度に対応するPuやUの同位体組成を，この同位体テーブ ルより抽出して，燃料集合体全体で高さ方向に積分する 
ことで，燃料集合体に含まれるPuとU量を得る。この量 を払い出し量とする。

BWR では, 炉心全体の熱出力, 冷却材流量, 中性子 束分布等の実測值をもとに，プラントに設置された専用 の計算コード (プロセス計算機)を用いて燃料集合体毎の 出力分布, ボイド率分布, 流量分布を求める。これを運 転時間で積分することで，運転サイクル毎に燃料集合体 の燃焼度と, 履歴ボイド率 (ボイド率の運転サイクルの 期間での平均值) 分布を求める。一方, 燃料集合体の燃 焼度と履歴ボイド率をパラメータに燃料集合体水平方向 を 2 次元でモデル化した集合体燃焼計算を行って，同位 体テーブルを作成し，この同位体テーブルから燃焼度と 履歴ボイド率に応じた $\mathrm{Pu}$ や U 量を得て, 燃料集合体全 体で高さ方向に積分することで, $\mathrm{Pu}$ と U の払い出し量 とする。

同位体テーブル等は新しい種類の燃料集合体の導入等 を機に更新されている。テーブルの作成に用いる燃焼計 算は, 1970 年代から現在に至るまで, 計算モデルや核 反応データベース (核データライブラリー)の改良・改善 が進められている。そのため, RRP アクティブ試験に 供された燃料集合体の中では，第 2 図に示すように, 70 年代に使われた燃焼計算コードで核物質量を評価さ れた燃料と, 現行コードで核物質量を評価された燃料が 混在している。

\section{2. 受け入れ側の計量分析}

RRP では, 1 回の作業 (1 キャンペーン) で数十から数 百体の燃料集合体がアクティブ試験で用いられ，SRD はキャンペーン毎に評価された。第 3 図に示すように, 燃料集合体はせん断された後, 溶解槽に送られて硝酸溶 液で溶解される。この溶液は清澄機で不溶解残椬と分離 された後, 入量計量槽に移され, 質量分析法等によって $\mathrm{Pu}$ や U の濃度, 同位体比, 容量が測定される。不溶解 残椬を含む廃液や燃料被覆管せん断片 (ハル), エンド

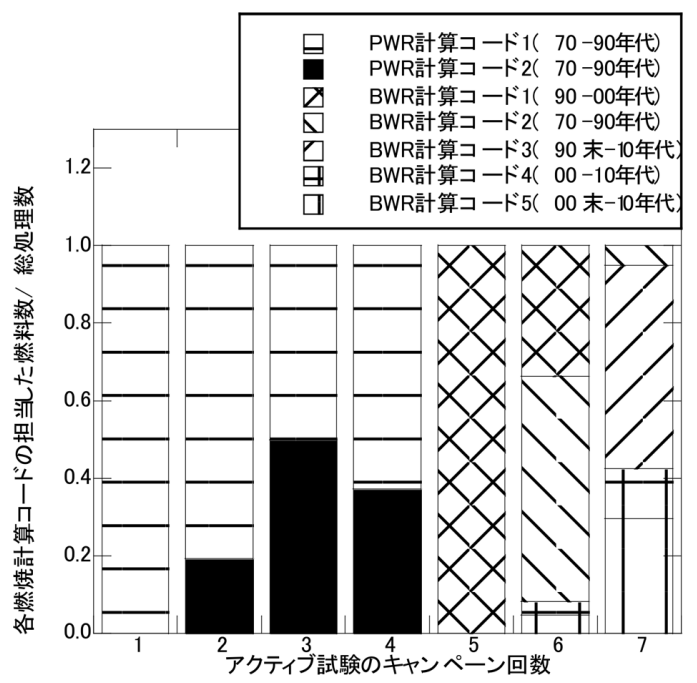

第 2 図 RRP アクティブ試験に供された燃料集合体の核物質 量評価に用いられた各種燃焼計算コード割合

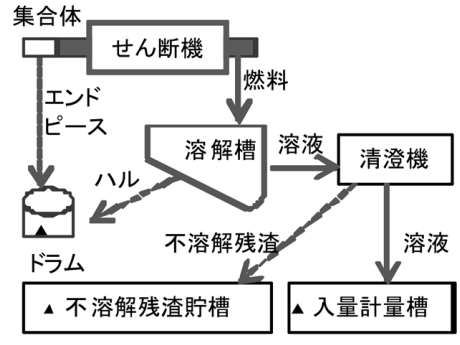

\の箇所で計量

第 3 図 RRP の計量点の概要

ピースに付着した核物質量についても計量が行われ，配 管等に付着した成分も評価されている。 RRPでは, IAEA もこれらの検認を実施しており，RRPとIAEA の核物質計量值はよく合致している。

II.1 節で述べたように, RRP のアクティブ試験では, 同じキャンペーンでも様々な燃焼計算コードで組成が評 価された燃料集合体が同時に処理され，それらをまとめ た条件で SRD が評価されている。

\section{SRD の発生要因の検討}

\section{PWR の燃焼計算の調査}

PWR における出力・燃焼度分布の計算は，取替炉心 設計值と中性子束測定值等との照合によってその精度が 確認されているため, SRDの主な要因は同位体テーブ ルを作成している燃料集合体の燃焼計算にあると考えら れた。

1970 年代から使用されていた旧来の燃焼計算コード には，計算機性能や記憶媒体の容量の制限のため，現在 と比較すると多くの近似が使われている。委員会で検討 した結果, $\mathrm{Pu}$ の生成量に影響した項目として，以下が 抽出された。

(1) 核物質の燃焼に伴う核変換の計算で用いる燃焼 チェーンで ${ }^{238} \mathrm{Pu}$ の生成を考慮していなかった。 1970 年代当時, 使用済燃料の燃焼度が低かったた め，炉心管理では ${ }^{238} \mathrm{Pu}$ の生成まで考慮する必要性 が小さかったからである。

(2) 燃料性能は同様であるが，ペレット径が少し異な る二種類ペレットが用いられているが，一部のプラ ントで両者を同等に取り扱う近似を用いて $\mathrm{Pu}$ 量が 算出された。ペレット径の違いにより $\mathrm{Pu}$ の生成量 も数\%変化する。

（3）中性子吸収体扦入履歴の考慮が詳細ではなかっ た。ガドリニウム添加燃料の導入以前は, 燃料集合 体には運転サイクル初期の反応度を抑制するために ホウケイ酸ガラス等で構成される中性子吸収体が挿 入されていることが多かったが，中性子吸収体の挿 入により中性子スペクトルが変化するため, $\mathrm{Pu}$ の 生成量に影響する。

以上の項目の各々について影響を評価し, $\mathrm{Pu}$ の生成 量は, (1)と(3)の考慮で増加し, (2)の考虑で減少すること 
を確認した。次にこれらの事項の SRD への影響を調査 した。アクティブ試験に供された燃料集合体の軸方向の 燃焼度分布の実測データは，すでに炉心管理で活用済み のため処分されている。そのため再計算するに当たって は別途，設計計算の燃焼度分布を用い，補正係数を導入 することで，旧燃焼計算コードと同様の計算を，現在の 燃焼計算コードで実施し，（但し，(1)〜 (3)の項目を考慮 した計算)，SRDを再評価した。その結果，第 4 図に示 すように Puの SRD が減少 (改善)することを確認した。

\section{BWR の燃焼計算の調査}

BWR では，プロセス計算機と，燃料集合体燃焼計算 コードに SRDの要因が求められた。プロセス計算機を 用いた 3 次元炉心計算による集合体燃焼度, ボイド率の 評価では，中性子束測定值を用いているため，SRDに 影響を与える燃焼度, 履歴ボイド率の誤差は出にくく, また炉心や燃料集合体の幾何学的な製造公差，炬心熱出 力の誤差が SRD に与える影響も少ないことを確認した。 そこで集合体燃焼計算コードを調査した。現行の国内の 燃料集合体燃焼計算コードは 3 種類あるが, ベンチマー ク計算によりこれらの差は $\pm 3 \%$ 以内であることを確認 した。これら現行の計算コードは，燃焼計算の詳細化や ガドリニウム $(\mathrm{Gd})$ 入り燃料の幾何学モデルの詳細化等 の改良が進められている。そのため, 改良前の旧コード で評価された SRD と現コードで再計算した SRDの比 較を行った。

BWR \& PWR と同様に, アクティブ試験に供された 燃料集合体の軸方向の燃焼度分布等の実測データは, す でに炉心管理に活用済みのため処分されている。そのた め，再計算するに当たっては別途，代表的な燃焼度分 布，履歴ボイド率を用いて新/旧燃焼計算コードの解析 の比較を行い，それを基に近似的に現行燃焼計算コード による払い出し量として評価した。これを第 4 図に示 す。現行燃焼計算コードにおいて核データライブラリー や計算手法の更新により，Puの SRD が減少することが 確認された。

また，BWRの核物質量の評価で，さらに詳細な燃焼 履歴を将来取り入れることで, Puの SRD がさらに減少 し，改善する見込みであることを解析により確認した。

\section{IV. 今後への提言}

PWR, BWR を通じて, 燃焼計算コードは, 核データ 処理の精緻化, 中性子エネルギー群構造の最適化, 燃焼 チェーンの拡大などが進められており，燃焼計算の精度 が向上する方向にある。今後は, 核種生成量に関する計 算ベンチマーク，使用済燃料の照射後試験データ等との 比較, そして RRP での再処理事業の進展に伴い評価の 進む SRD の傾向を分析，議論し，各燃焼計算コードの 手法の改善に反映していくことが望ましい。さらに改善 された燃焼計算コードで払い出し量を再計算すること

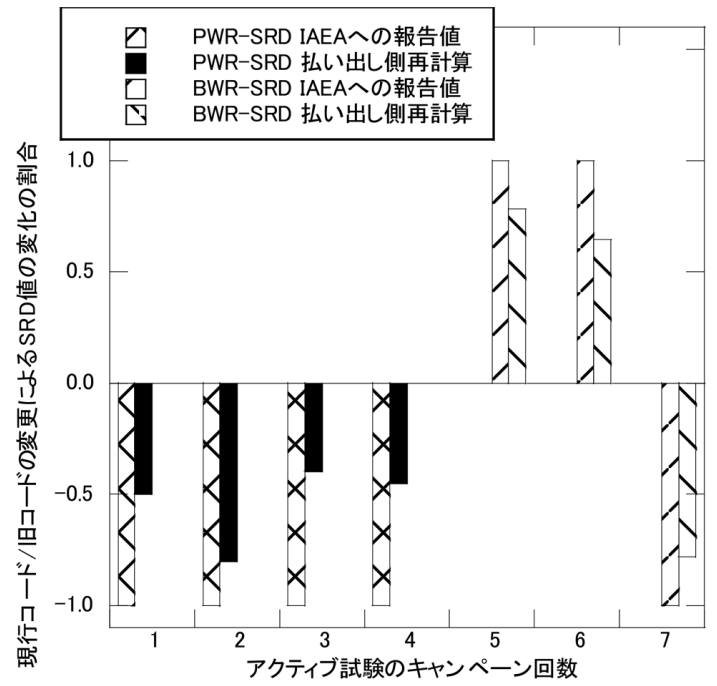

第 4 図燃焼度・履歴ボイド率等を仮定した現行の集合体燃焼 計算コードで再計算したSRD の改善状況

で, 評価済みの SRDの改善も期待できるので, その集 合体燃焼計算の入力データとして

・初期ウラン重量を含む燃料集合体の製造仕様,

・3 次元炉心計算に用いる熱水力計算用データ,

・燃料装荷配置及び中性子吸収体の挿入履歴,

- 炬心熱出力, 制御棒位置, 測定中性子束分布,

等のデータ保管を提言した。

\section{V. 結 び}

$\mathrm{SRD}$ の発生要因として燃焼計算を分析し，その主要 因を特定し, 今後 SRD の低減が期待できる方向にある ことを示した。本委員会の活動状況は, 国を通じて IAEA へ報告され, IAEA も同活動を, 我が国の保障措 置に対する積極的な取り組みとして認めている。また, 本委員会の提言に応じて, 各電力会社は, 将来の SRD 再検討に必要な炉心運転情報の保存手段を準備してい る。今後, SRD が評価された際は, それを分析し, 燃 焼計算へフィードバックすることが望ましい。産官学を 集めた本委員会は, そうした将来の議論の場の礎となる ものである。

著者紹介

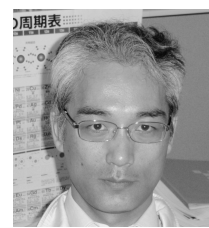
名内泰志 (なうち・やすし) 電力中央研究所 (専門分野) 原子炬物理，放射線計測

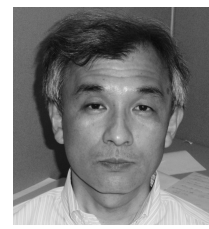

笹原昭博（ささはら・あきひろ）

電力中央研究所

(専門分野) 原子炉物理, 核燃料工学 